\title{
Beautifully violent: the gender dynamic of Scottish karate
}

Chloe Maclean

This is an Accepted Manuscript of a book chapter published by Routledge in Global Perspectives on Women in Combat Sports, on 26/08/2015, available online: https:// www.palgrave.com/gb/book/9781137439352 


\section{Beautifully Violent: The Gender Dynamic of Scottish Karate}

\section{$\underline{\text { Introduction }}$}

Within what has been called 'the crisis of masculinity', sport has been cited by many scholars as a key domain for men to construct a masculine identity which reproduces and legitimises (hierarchical) distinction from women (Burstyn, 1999; Connell, 1990; Hargreaves, 1994; Whitson, 1990). With commonplace socio-historical beliefs suggesting violence as a 'natural' and essential part of what it is to 'be' a man (Bourdieu, 2001:53), combat sports have become a growing field of interest for many sport scholars exploring constructions of gender (Hirose and Pih, 2010; Spencer, 2012; Wacquant, 2004; Woodward, 2006) with growing attention being paid to women's experiences, gender constructions, and potential gender subversions, in such socio-historically 'masculine' sports (McNaughton, 2012; Mennesson, 2000; Velija et al, 2012). Yet with a few notable exceptions (Channon, 2013; Channon and Jennings, 2013; Guerandel and Mennesson, 2007) there remain very few academic studies which take a direct focus on the phenomenon of sex integration in combat sports, and what impact violent intercorporeal interactions between men and women have on ideas, negotiations, and performances of gender.

In this chapter I explore the mixed-sex training of karate in Scotland with a specific focus on how women and men negotiate ideas of difference and similarity through sharing the darting punches, hard kicks, agile footwork, soothing and straining stretching, elegant performance of technique, sweat-dripping pad work, and the physical and emotional bonding, of karate training together. In delving into the swift, aggressive, and intimate mixed-sex training of karate, this chapter seeks to illuminate the ways in which conventional understandings of women's bodies and capabilities are challenged/reinforced within the sport's 'uni-sex' structure, how 'appropriate' gender performances and interactions between women and men are negotiated accordingly, and how this constructs a rather layered and complexly gendered setting.

\section{Sporting Gender}

Bodies play a central role in the re/production of gender. Bodily differences are used as markers to distinguish men and women as social groups, to attach meanings, and from these meanings construct characteristics presented as innate to men (masculinity) or innate to women (femininity) (Connell, 2009; Gatens, 1996; Hargreaves, 1994). Connell (2009) suggests ideas of men and women's distinct 'natural sexual characters' act to legitimise dualistic expectations and appropriate behaviours of women and men. Furthermore, Connell suggests that notions of masculinity and femininity are imbedded with implicit power relations which act to both present gender identity as two distinct, exclusive, and clear cut categories tied to respective sexed bodies; and to construct a gender order subordinating women, femininity, and masculinities which deviate from a hegemonic, idealised form. 
Whilst the above might seem to paint a rather deterministic picture of gender, the degree to which these structures of gender are adopted and enacted by individuals provides room for more flexible embodiments of gender identities. West and Zimmerman (1987) argue gender is something actively 'done' reflective to normative conceptions of 'appropriate' and 'inappropriate' behaviours expected of one's sexed body. It is made and remade in a 'situated doing' (West and Zimmerman, 1987) reflective to the expectations of men and women in a particular field. As something performed and subject to critique, the notion of 'doing gender' highlights the fluid, relational, constructed quality of gender identity, alongside providing space to understand gender as something actors have agency in embodying. As something actively 'done', individuals have opportunities to deviate from gender expectations tied to one's sexed body, and in doing so potentially subvert conventional notions of masculinity, femininity, and the perceived differences between men and women, thus challenging the construction/legitimacy of a gender order within a given field. Indeed it opens up possibilities for gender to be played with, unravelled, and potentially 'undone' (Deutsch, 2007).

Due to the centrality of bodies to sport - as the vehicles for action, success, and play - and the centrality of bodies to ideas of gender (with sporting bodies a particular crux of masculinity (Connell, 1990)), sport is an arena argued to hold particular potential to subvert conventional notions of women's bodies, femininity, and women's subordination (Blinde et al. 2001; Connell 2012; Dworkin and Messner, 2002; Hargreaves, 1994; Therberge, 1987). By women participating in the 'masculine' domain of sport, the exclusivity of the domain (and the skills involved in its practice) to men is challenged, alongside conventional gendered notions of women as fragile, passive and weak (Dworkin and Messner, 2002). Sport is an arena which highlights flaws in the applicability of certain ideas of femininity to women athlete's bodies, and ideas of masculinity as exclusive to men's, opening avenues for new meanings and understandings to be attached to women's bodies (Butler, 1998). The closer women's physical practices come to men's physical practices, the further myths of bodily differences which invoke different 'appropriate' behaviours for men and women can be unravelled, and the further sport's position as a key pillar for legitimising ideas of (hierarchical) gender difference can be dismantled (Connell, 2012).

The vast majority of literature advocating sport's potential to challenge restrictive and hierarchical notions of gender has primarily focused on sports where gender is constructed in single-sex settings. In single-sex contexts gender is constructed and performed in relation to an idealised version of the other, rather than actual men or women, where the mosaic of both 'masculine' and 'feminine' characteristics that real people embody in sport - and in life - are hidden from view. In turn, this works to maintain ideas of 'natural' difference in relation to an absent other (Channon, 2013; McDonagh and Pappano, 2008). As such it is unclear either the extent to which challenges to established ideas of gender made in single-sex arenas can escape being reduced back to ideas of difference, or how far such challenges can transcend into mixed-sex areas of wider social life.

In this respect, a small but growing literature on mixed-sex sport training is developing, which allows insights into the relational negotiations of difference between men and women, and as such gender identities, within what is arguably still a 'male domain' (Burstyn, 1999). 
Despite the egalitarian potential (and sometimes implicit aims) of sex-integrated sport, existing literature suggests this potential has not yet been fulfilled. Rather, participation and play in sport is often dominated by men (Henry and Comeaux, 1999; Hills and Croston, 2011); the enforcement of 'gender-equalising' rules of play paradoxically reinforce ideas of differences between men and women (Henry and Comeaux, 1999; Wachs, 2002); individuals often reproduce conventionally gendered performances/narratives (Grindstaff and West, 2006); and above all, ideas of differences between sexed bodies do still surface, reproducing (to varying degrees) conventional dualistic notions of gender which undermine women's (suit)ability to sport in comparison to men's (Channon and Jennings, 2013; Henry and Comeaux, 1999; Hills and Croston, 2011; Wachs, 2002).

The egalitarian potential of sex-integrated sports fights against a tide of societal ideas and beliefs which suggest all women's bodies are physically very different, and less equipped for sport, than all men's (McDonagh and Pappano, 2008). These beliefs present the idea of sex-integrated sport as unequal and unfair in itself, and underlie the egalitarian limitations of sex-integrated sport cited above. Sex-integrated sports may not have reached an egalitarian ideal yet, however they do create spaces where the similarities between women and men athlete's bodies can be exposed, and certain myths of men and women's 'natural' sexual characters debunked (Anderson, 2008). Through experience of training with both men and women, individuals experience first-hand the capabilities of members of the opposite sex, which bring ideas of distinct gender difference, and a hierarchical gender order between men and women, into question (Anderson, 2008; Channon and Jennings, 2013; Guérandel and Mennesson, 2007). The display and experience of men and women performing sport together allows the abilities of some women to be exposed as better than that of some men, and although this might not equate to instant egalitarian play, it does begin to mediate the idea of sporting ability as resting on a continuum, with women and men interspersed across the spectrum, rather than sitting at binary positions (Anderson, 2008; McDonagh and Pappano, 2008). By highlighting the interspersion of men and women across the continuum of sporting ability, mixed-sex sport draws into question underlying understandings of men and women's bodily differences which usually justify sex segregation in sport, and in doing so, problematises ideas of gender difference these entail.

As a site so closely associated with masculinity, exposing a continuum of skill in mixed-sex combat sport is suggested to hold amplified gender-subversive potential for women (Channon and Jennings, 2013; Noel, 2009; McCaughey, 1997; McNaughton, 2012). In these sports women are encouraged to enact and acknowledge the capabilities of their bodies to execute an idealised crux of masculinity - fighting - in direct combat with men, and consequently in doing so, alter their embodiment of gender. Drawing on the ideas of physical feminism (McCaughey, 1997) - that the physical power differences between men and women act as key mechanisms for oppressing women - Noel (2009) and Velija et al. (2012) suggest that through the acquisition of fighting skills developed with men, women can reduce their physical power differences to men, and in turn renegotiate ideas of women's vulnerability, and feminine fragility. Embedded within combat sports, normalised mixed-sex practice illuminates how some women can and will be better fighters than some men (Channon, 2013; Guérandel and Mennesson, 2007), thus not only reducing physical power differences between the two, but surpassing them in some cases. Women's ability to defeat 
men in combat undermines ideas of combat as exclusively inherent to men's bodies as opposed to women's, and challenges a gender order privileging men based on such assumptions. McNaughton (2012) and Guérandel and Mennesson (2007) further suggest that combat sports not only provide an arena for women to gain what are deemed to be masculine qualities, but also an arena where women can, and do, construct 'postinsurrectionary' gender identities: identities which actively both challenge conventional notions of femininity though the performance of characteristics/actions deemed to be masculine, and at the same time embrace conventional femininity through the performance of actions conventionally deemed feminine.

In actively embracing both conventionally 'masculine' and 'feminine' characteristics, such a fluid approach to gender performance by women in combat sport draws the hierarchical position of masculinity to femininity, and their ascription to particular sexed bodies, into question, creating complications for the construction of a gender order. As the reduction of physical differences between men and women dissolves the bases for constructing distinct masculinity and femininity, and notions of all women as inferior athletes to all men are debunked by women visibly defeating their male training partners, the existing literature on mixed-sex combat sports suggests these arenas hold great potential for practitioners to reconstruct interpretations, performances, and power relations embedded in the embodiment of gender.

To illuminate Scottish karate's specific gender-subversive potential as a mixed-sex combat sport, it is firstly important to outline the gendered context surrounding the practice of karate in Scotland.

\section{The Gendered Context of Scottish Karate}

The practice of karate is founded on a (continually reimagined) history of the sport that blends Eastern mythology and the aftermath of World War II (Krug, 2001; Tan, 2004). Whilst judo was banned in Japan for several years after World War II for being deemed to incite a philosophy of militarism, karate was interpreted by the Western allies as a boxing-like practice, with a softer philosophy seen to promote ways of living a humble, graceful, moral life (Tan, 2004). The Western allies' acceptance of karate, as popularised by Gichin Funakoshi (1868-1957), helped the martial art to accelerate across the Western world. In this process, the form of karate was reshaped fusing Western conceptions of Funakoshi's teachings and ideas of Eastern philosophy, with competitive, rule-based, structures of sport (Krug, 2001).

In drawing on both a framework of (mythologised) Eastern martial-art philosophy, and a framework of Western sport, karate practice embraces characteristics conventionally understood as masculine and feminine in Western terms, steering away from a strictly masculinised sport paradigm. Less emphasis is placed on physical strength, dominance, and physical strength as a source of dominance, which are often used to legitimise ideas of sport as a 'male domain' (Burstyn, 1999). Rather, karate's framework blends this alongside placing importance on precision, elegant control, and crafting a personhood which is 'outwardly gentle, inwardly strong' (Funakoshi, 1938:71). Through the combination of these 
frameworks, karate has been seen as a martial art/sport suitable for all bodies, leading to a naturalised arrangement of men and women to train together.

As one of the first countries to which senior Japanese Senseis took the sport, Scottish Karate is founded on a successful history - or, more specifically, a history of successful men. From the 1970s through to the end of the 1980s, Britain was a leading karate nation, and consistently Scottish men featured (over representatively) in the team (Summersdale Productions, 2006). Nearer the end of the 1980s Scottish women too started to find their place in the British team, not long before the British team split and Scotland started competing as its own national team at European and World championships. Predominantly these initial successful Scottish women were daughters of successful men, coming from families of karate athletes. Yet there has long been a will to encourage women in the sport. In the Scottish Karate Federation Gazette of 1994 Hamish Adam, the chair of the association, made a specific call to support the development of women within the association:

'I would like to suggest to all our club instructors that they take an active stance in encouraging their female members to participate in more competitions. In this way we can bring back the days when our women's team had an unbeaten run of six years at the Scottish National Championships' (Adam, 1994:2).

Since the initial presence of these successful women, there has been an influx of women in Scottish karate post-1980s to today where some clubs, although very few, have more girls/women practitioners than boys/men. Most clubs appear to have a ratio of around 3040 percent women to $60-70$ percent men ${ }^{1}$. Although an increasing amount of women are entering the sport, women remain almost absent amongst the structure of the Scottish Karate Governing Body (SKGB). Despite encompassing over 10,000 licensed members, 32 karate associations, and 272 active coaches, all members of the board of directors and subsection committees are currently men. The SKGB have recently acknowledged this lack of women within their organising structures and are currently developing a position to look after the interests of women in the sport ${ }^{2}$. Nonetheless, Scottish karate is currently an arena infused with women, some very successful women, sweating, fighting, laughing, and training alongside men; but organised, structured and steered by men.

Within this context, and in light of the combat sports literature, how then are ideas of women, their bodies, and gender difference, negotiated within Scottish Karate? And how does this impact upon performances of gender, and conventional notions of a gender order subordinating women and femininity?

Methods: 'Slipping into the Skin' of a Karateka ${ }^{3}$

\footnotetext{
${ }^{1}$ This is an informed estimation based on the author's personal familiarity with multiple Scottish karate clubs, and the opinions of participants in this research. Actual data are not presently available.

${ }^{2}$ See www.skgb.com for more information on this development.

$\underline{3}$ Japanese term for karate practitioners.
} 
The findings in this paper are drawn from a six-month exploratory ethnographic study involving participant observations and interviews across three karate clubs in central Scotland - Kaizen, Central Dojo, and Budo Midlothian ${ }^{4}$ - with the aim to gather a small but rounded glimpse of the Scottish Karate community (Hannerz, 2003) with a focus on how gender is situated, experienced, negotiated, and performed by its members within karate club contexts. In the terms of Wacquant, the aim was to gain an insight into the embodied, carnal, gendered experience of the sport - to 'slip into the skin' (Wacquant, 2004:8) of Scottish Karateka.

The three field sites chosen sit as examples of typical structures and forms karate clubs in Scotland take. The Central Dojo and Budo Midlothian clubs were defined by the karateka I trained with as 'normal' karate clubs in Scotland in their demographic make-up and structure of practice: their adults classes hold around 15-20 participants aged between 16-50 years old with roughly 30 percent women and 70 percent men. Their classes mix elements of stretching, technique work, pad/fitness work, kata, and sparring, giving a full rounded flavour of karate. Kaizen karate club places a far stronger focus on sparring oriented towards competition, and as a result has a highly successful competitive record both nationally and internationally. The competition-oriented format of Kaizen karate club is one increasingly being adopted by clubs across Scotland, whereby karateka specialise in either kumite (sparring) or kata (a solo performance of a routine arrangement of karate techniques) and predominately steer their training towards competition for their respective discipline. In this, kata is often seen as the softer, 'feminine' side of the sport, and kumite the more aggressive, 'masculine' side; however, each discipline has both many men and women competing in them, with kumite appearing to be the more popular of the two among both sex groups. Kaizen's classes hold around 40 people aged 14-30 years, interspersed with national and international champions. It also holds a closer gender balance than Central Dojo and Budo Midlothian at around 40 percent women to 60 percent men. These clubs combined allowed an insight into gendered experiences of what I perceive as typical karate practice in Scotland.

Framing my data collection and analysis is my position as a karate athlete myself, a member of the Kaizen Karate club, and a member of the Scottish National Karate Squad. In many ways I could be seen as not only an insider, but an intimate insider (Taylor, 2011) - a friend to most, a role model perhaps to those less experienced and/or aspiring to competitive success, and to all a fellow karateka with the same binding passion for the sport. Even without knowing who I was, in entering the karate clubs wearing a black belt - a symbol of skill, dedication, and commitment to the sport - I was fast-tracked to the heart of the clubs, made to feel part of the clubs, and given trust and respect as a fellow karate athlete. The intercorporeal experience of sharing a hobby/passion, and seeking to share it with others, held an almost instantly bonding effect, where both myself and the karateka I trained with held a relative embodied empathy for the other. Such embodied empathy can accelerate and deepen understandings of each other, creating respectful relations and rich, grounded, data:

\footnotetext{
${ }^{4}$ Pseudonyms used for all karate clubs and participant names.
} 
'through authentic engagement, the lines between researcher and researched blur, permitting each other to explore the complex humanity of both self and other. Instead of 'speaking for' or even 'giving voice', researchers get to know others in meaningful sustained ways.' (Tillman-Healy, 2006:277).

Equally, my position within the fabric of Scottish karate instantly dilutes typical ethnographic issues such as gaining access, understanding the language of the field, and building rapport and trust with club members, allowing the conduct of intimate, in-depth research based on a genuine shared empathy and respect with the other karateka. ${ }^{5}$

Participant observations were the initial and primary data source, involving training once a week at each club, alongside observing and participating with the clubs at two competitions, and taking part in their social events such as fundraisers and club awards dinners. The majority of data is drawn from club training as, comparative to competitions and social events which occur occasionally, club training builds up the everyday experience of the sport, and as such allows insights into the layers of regular, 'normal', minutiae of karate practice intrinsic to the production, or dismantling, of gender in the field. Kaizen karate club's focus on competition sparring allowed for a greater depth of data and thematic insight into the tacit mixed-sex sparring experience in particular, whilst Budo Midlothian and Central Dojo aided in illuminating my own 'insider' gendered predispositions of karate training by experiencing and exploring the varying (although similar) karate practices of these clubs. Following from and informed by observant participations, 12 semi-structured interviews were conducted (Kaizen $n=6$; Central Dojo $n=3$; Budo Midlothian $n=3$; women $n=6$; men $n=6$ ). The motivation, experiences, and meanings attached to the sport inevitably vary from beginners to well-established members, and thus it was useful to capture insights from varying levels of karateka to explore the karate-gender nexus.

The combination of the two methods generated insights into both the intercorporeal interactions, performances, and relations of women and men karateka; and the experiences, perceptions, and beliefs of gender informing, and informed by, such interactions. The results of the study and its analysis can be broken into three components which frame the gender dynamic of karate in Scotland: The hierarchy of status; Karatekas' perceptions and performances of difference; and the prioritisation of masculinity.

\section{The Hierarchy of Status}

Embedded within the philosophy of karate is a respect for one's position within the hierarchy of ability: 'Principle one: Do not forget that karate-do begins and ends with rei (respect)' (Funakoshi, 1938:20). Ability is visibly marked by coloured belts which reinforce correct interactions, respect, and hierarchical positioning between karateka. Status is awarded through achieving and displaying good karate skills in fighting and training drills, and in karate achievement is not confined to men. Men and women are expected to carry out the same tasks and training drills as one another to achieve their belts and status. It is in this

\footnotetext{
${ }^{5}$ There is not the space here to fully discuss the benefits and consequences of insider positionalities. For discussion on the problems related to insider positions see Merton (1972) and Taylor (2011).
} 
uniform, 'one size fits all' setup where roles and distinctions of men and women begin to blur, creating space for interpretations of women's bodies to be re-conceptualised, and a conventional gender hierarchy renegotiated (Anderson, 2008).

Within the clubs surveyed, women often held higher belt grades than men, and sometimes the ones who were feared the most as physically intense sparring partners. Successful female athletes were paraded in the club as much as their male counterparts of equal skill level, and were looked up to as role models by both men and women:

'We're really lucky we've got lots of good women here. Lots of good men too, but lots of black belt women who train really hard. I try to train with them as much as I can, trying to learn how to be like them! You need to train with people better than yourself to better yourself.' Carla, formal interview, 10/12/12.

'Sam - she's the one in the club everyone's scared to fight! She has no fear. It's always brilliant to fight her or train with her... but you just know a kick in the face is just around the corner!' Jack, field interview, 14/11/12.

The respect afforded to the women of the karate clubs could be seen and determined in the sparring sections of the class where women, men, tall, small, old and young would all mix and mingle to perform their art. The fights would change quickly so that the athletes had the opportunity to spar with as many people as possible, all of whom hold differing strengths and pose different challenges. In choosing who to fight, the classes divided predominantly by height and weight rather than sex, with women and men frequently choosing each other as partners. The queues to fight some of the skilful women in the class were just as long as those waiting to fight skilful men. And equally it was sometimes women in the clubs who were felt to be the hardest fighters, or best technicians of their sport. The karateka reflected on this as karate being a sport which embodies a plurality of physicalities that can perform exceptionally with varying specialties and obstacles:

'You need to fight to suit your height and weight, that's what good karateka do really. Everyone's got their technique, everyone has something to give.' Paul, field interview, 20/2/13.

'If I want to work on my control, I would go with someone small and nippy. If I want to get sharper with my movement l'd go with one of the big guys who I can't afford to be hit by. Who I want to fight just depends on what I want to work on really.' Abigail, field interview, 20/2/13.

It is in this space that the idea of a hegemonic (masculine) fighting body appears to be broken down, allowing varying builds of men and women the potential status of top fighter. In these one-to-one battles women are provided the opportunity to directly contend with men to be the best fighter in the club, and may prove themselves to be so. The interchanges of stinging punches and thumping kicks between men and women were reflected on by the women as an empowering, rewarding, part of karate - a tacit symbol to their skill, strength and respect in the sport (see Channon and Jennings, 2013). Sarah highlights this:

'I really like fighting with the guys. We've got some really good guys and it's good because they know they can properly fight you. You can hit them hard and they'll do 
it right back. And then if you do catch them with a really good kick or something- that feels amazing. It's like you can show them that you're a woman and an amazing fighter. And they accept that - they have to, ha-ha!' Sarah, formal interview, 21/1/13.

In my own field notes I reflected similarly:

The hits were coming thick and fast: I'd catch him with a face punch, he'd instantly respond with a big body kick slamming into my side, l'd come back at him with a burst of combinations... It was both brilliant and nerve-wracking. David is a good few stone heavier than me and about 9inches taller, so his hits were hard, and his reach made it trickier for me to sneak in to attack without getting hit on the way in. But nonetheless, if he hit me, I wanted to hit him back quicker and better - and he seemed to feel the same way- making it a great fight to be part of. Field-notes 23/2/13.

Due to karate's embedded philosophy of hierarchical respect, and its unisex training practice, women are given a relatively unique opportunity to be more skilled than men, and be recognised and celebrated as better than some men. Here, the fights and training drills between men and women are negotiated on a basis of skill, where everyone wants to be the best, giving women the chance to contend directly with men for 'sporting capital' (Mennesson, 2000:25). Particularly within a sport which has traditionally had connections to masculinity, the ability for women to achieve positions above men within the hierarchy of status presents challenges to notions of a gender order and hegemonic masculinity (Anderson, 2008). In doing so, it creates a space where women can be respected by men, feel respected by men, and realise their bodies' potential to be skilfully 'violent'. Simultaneously, men too learn to read women's bodies beyond conventional notions of femininity (Noel, 2009), and build a bonding respect with women for their skill in the sport.

\section{'The Woman's Fight' vs. 'The Man's Fight': Fighting with Ideas of Difference}

The renegotiations of gender roles, positions and expectations of women in the karate club founded on their asserted skills in technique, determination, and competence in combat come into conflict with expectations of women, and femininity, held outside the club (Butler, 1998; Guérandel and Mennesson, 2007). Due to its combative nature, karate is typically seen and understood as embodying many stereotypically assumed masculine traits: aggression, strength, violence, dominance, pain, and self-interested self-pursuit. But in practice, it blends all these conventionally masculine behaviours with those conventionally seen as feminine - elegance, control, agility, flexibility, patience, and support. In this blend of masculinity and femininity, karateka found space to both reproduce ideas of difference by realigning women with conventional notions of femininity, but also simultaneously refute the appropriateness of such realignment by recognising similarity: 'Principle 4: First know yourself, then know others' (Funakoshi,1938:34)

One of the primary ways in which this was done was through constructing ideas of 'the woman's fight' and 'the man's fight'. Every fighter fights differently; however, interviewees perceived women and men to have more 'naturally suited' fighting styles (Guérandel and 
Mennesson, 2007) which reflected conventional notions of masculine and feminine characteristics within sport:

'I really enjoy training with the guys because I think they have a different way of thinking than we do. Men can obviously hit harder and look for those kinds of hits.' Sarah, formal interview, 21/1/13.

'I'd say there's small differences in how men and women fight. Not big differences, but small ones. Like y'know, women usually have a bit cleaner - extravagant maybe - technique. Just small things like that.' Paul, formal interview, 27/1/13.

The perceived variation in fighting styles embedded societal expectations of women's bodies as elegant and fragile compared to men's. As such, injuries to women caused by men raised heightened tensions for women karatekas' position as both fighters and women. Amongst the darting movements of fighting bodies, when men hit women hard causing injury the fights would hit a standstill. Once hurt, focus returned to the femininity of the woman, reinstating conventional societal interpretations of women as fragile, aesthetic, and to be protected (Channon and Jennings, 2013). As a result, the man in question would often appear reluctant to attack her again for the remainder of the fight, and the suitability of women as karateka would fall into question:

'I'm a fan of women and men fighting but I'm not a fan of...I mean me, fully punching you in the stomach, and then what if you want to have children? I just don't like it.' Steven, formal interview, 3/2/13.

Similarly, in talking about her plans for the weekend, Jenny highlights the conflict of doing a 'masculine' sport and maintaining expectations of feminine beauty for the world outside of the dojo:

'Jenny joked of how her husband had warned her that her arms are getting bigger due to gaining muscle and suggested 'you don't want them any bigger do you? What will you look like at the office party next week in your dress?!'. She laughed this off , but equally reflected an uncertainty in her face, almost looking at me for reassurance or guidance as to how to feel about her growing muscles. She continued negotiating her seemingly unsure position on the subject whilst maintaining a lighthearted, jokey tone: 'I mean, I just want to keep healthy anyway, I don't need to get big strong muscles really' to which Nick replied 'Better than bingo wings anyway! Ha-ha!' Fieldnotes 23/2/13.

The interlude of jokes around Jenny's arms from both her partner and Nick, although opposing comments from each, both reinforce ideas of women's bodily beauty as centrally important in 'doing womanhood', and an expectation which at times came into conflict with her identity as a karate athlete (Butler, 1998). As such, societal expectations of gender differences and conventional notions of femininity intermittently inscribed women karateka's bodies as fragile and aesthetically important, temporarily masking their skill, strength, and success, and ultimately questioning their equal suitability to the sport.

Yet, the extent to which interpretations of difference and conventional femininity reflected the reality of women's bodies and fighting 'style' was sought with question and confusion. 
The practice of women and men seemed almost identical, and varied more between different physicalities rather than different sexes. Both men and women would utilise hard hitting punches, elegant movement, and aesthetically stylised kicks. In reflecting on themselves and women they knew, ideas of difference and women's fragility appeared to be something which the karateka found less legitimate:

'Yeah there's differences between women and men's fights. Guys are a wee bit more physical, some of them can be sharper...but it depends. I mean some guys are pretty crap and the women in the club always beat them. Actually, I take it back, there's lots of men I'm way sharper than!' Hayley, formal interview, 27/1/13.

'A girl could quite easily hit as hard as another guy can. It's not really about hitting hard in our sport.' George, field interview, 5/12/12.

'Look at Sarah, why would anyone go easy on her? She's tough as nails!' Scott, formal interview, 4/2/13.

With women hitting the same as, and being able to beat, some men, Hayley, George and Scott point out ways in which the differences between men and women's fighting were not so clear, if not in-fact more similar than different (Noel, 2009; Velija et al., 2012). This exposes the clash of expectations of gender difference, with the demands of men and women to perform the same task: to be agile, graceful, aggressive and violent to perform karate. The outcome of this clash is an exaggerated interpretation of differences in fighting styles and feminine markers of distinction to fulfil gender appropriate expectations of women (Guérandel and Mennesson, 2007). This sits alongside continuing doubts that such differences could really be applied to the respondents themselves or women karateka they knew and trained with. Through first-hand experience these women were seen to be strong, skilful, capable training partners. As such, the practice of training together allowed the contradictions of conventional gender expectations of women to be illuminated (McDonagh and Pappano, 2008), opening up avenues for karate women to be reinterpreted based on notions of similarity, rather than difference, to men.

\section{Man Up! Prioritising Masculinity and Overlooking Femininity}

The embodied blend of both conventionally masculine and conventionally feminine characteristics of the sport is crucial for karate performance: 'Principle 19: Do not forget the employment or withdrawal of power, the extension or contraction of the body, the swift or leisurely application of technique' (Funakoshi,1938: 107). Yet in describing the sport in interviews, and praising athletes who do well in the sport, it was the behaviours encoded as conventionally masculine traits that were emphasised, praised, and drawn upon. The conventionally feminine characteristics fundamental to the sport's performance were either hardly ever highlighted, or not part of the way the karateka spoke of the excitement and prestige of their sport.

A key emphasised principle of karate was being able to both give and receive a hit. Being hit is seen as 'part and parcel of the sport' and as such exaggeration of injury, or worse so 
crying, is frowned upon by Senseis and other karateka. Concurrent throughout karate is an ethos that:

'You've got to be fearless. If you've not got the right head for karate - forget it, wrong sport. You've got to be able to train with anyone, you've got to be able to not care (about getting hit).' Sarah, formal interview, 21/1/13.

Although being 'fearless' in giving and receiving hits was something recurrently expected of and done by women and men in the karate clubs, the degree to which karateka were expected to do so distinctly varied based on their sexed bodies. Joking banter, looks of disgust, or hard fights as punishment, were used to hold men more tightly to taking and giving hard hits. Based on orthodox notions of masculinity and the male body, they were expected to more readily embody and perform such aggression and strength (Anderson, 2008; Guérandel and Mennesson, 2007). The association of men to these 'masculine' aspects prioritised in understandings of karate equally lead to interpretation of men as more 'naturally' suited to the sport, and thus the ones who held the most potential to perform the sport best:

'I really like it (training with men), because obviously guys are a bit sharper and a bit stronger.' Abigail, formal interview,18/1/13.

'You need the guys that hit hard in the club, the ones that sort of toughen you up.' Paul, formal interview, 27/1/13.

Yet in practice, hitting hard and being hit hard is only a tiny element of what happens in karate training. In the structure of the martial art-come-sport strength plays a minimal role. Its practice indeed is for self defence with the idea that one hit should be all it takes to end the fight (Shobu Ippon), however what is emphasised as more important than the strength of an attack is its precise aiming, technical execution, and minimal exertion so as not to waste the body's energy or leave oneself open to danger. Karate's eclectic embrace of 'soft' and 'hard' uses of the body is exemplified in Kata. In this solo performative display of the soft, subtle, elegant, alongside swift and strong movements of the sport, it was often seen as something particularly suited to women (see Grindstaff and West, 2006), whilst at two of the clubs the sexuality of men who chose to specialise in kata was often questioned (see Hirose and Pih, 2010). Kata was equally regarded with less excitement or prestige than fighting:

'When people think of karate they think of fighting. So that's what most people want to do. Kata is fine, but it's not really my thing.' Scott, formal interview, 4/2/13.

'My sister's not much of a fighter, she's far more Kata. She's very, kind of, floaty and soft with her moves. She wouldn't last in fighting, but at least she can do Kata.' Carla, field interview, 3/3/13.

The comparative association of women's bodies to fragile, beautiful femininity and the more 'feminine' elements of the sport thus aligned women to a subordinated position in the sport. Women often attempted to directly divorce subordinated notions of femininity from their bodies by amplified performances of praised 'masculine' qualities such as being 'fearless'. For instance, when observing a particularly intense sparring session, I noted: 
Despite blood dripping from her nose Sophie insisted on continuing fighting: 'No, no, I'm fine.' Steven looked hesitant as Sophie continued trying to fight. Her eyes were filled with water, she probably could hardly see, but she insisted on finishing the fight as if she hadn't been hurt at all.. Field-notes 16/2/13.

In her insistence to keep fighting, Sophie attempted to rewrite her body, free from conventional understandings of fragile femininity, which questioned her suitability to a fighting sport. By virtue of enacting perceived masculine capacities, these performances seek to refute ideas of an inevitable tie between women's bodies and conventional notions of femininity, allowing women's talents to be recognised and respected (Mennesson, 2000).

In overlooking the value of the conventionally feminine aspects of the sport, a gender order prioritising masculinity was reproduced. Although karate is institutionally built around a genderless hierarchy, by interpretations of the perceived masculine behaviours aggression, strength, and a fearless spirit - as 'natural' and expected of men, women had to craft gender performances which emphasised their embodiment of these praised qualities to attain positions above men in the club hierarchy. In doing so, women were able to and attain a specifically masculinised form of sporting capital (Mennesson, 2000). These accomplished women were not seen as honorary men - one-off exceptions to gendered rules - as there were many women who were acknowledged as highly skilful karateka. Rather, they were seen as fighting against a natural disadvantage - not being a man - to be so skilful, and as such were highly respected by men for their achievements. In a complex twist, ideas of femininity both acted to subordinate women in the sport by suggesting their bodies and 'nature' were not as well suited to combat as men's, yet because of this, also acted to elevate the respect afforded to them as karate athletes when skilfully performing what were deemed to be masculine capacities (Anderson,2008).

\section{Conclusion: Towards a Mutual Respect}

'When you're training you get really strong bonds, like you push each other and you know you hurt each other, but you're making each other better. You push each other in the right direction. You don't get that opportunity with women much elsewhere.' Sean, field interview, 16/1/13.

Women occupy a complex position within Scottish karate: one which simultaneously deconstructs conventional notions of women, femininity, and the appropriateness of femininity to women's bodies; and at the same time reinforces ideas of women as a less natural fit to the sport. Through direct inter-bodily interactions between men and women, the practice of karate provides a space where the capabilities of women's and men's bodies can be re-learnt, and as such appropriate roles, interactions, and social positions reconstructed (Anderson, 2008; Channon and Jennings, 2013; Hills and Croston, 2012; McDonagh and Pappano, 2008). In the sport's strict hierarchy of status, karate women challenge conventional notions of their body as well as notions of a hegemonic masculinity, by the mastery of what are imagined to be masculine capacities. Men's grounds for hierarchical 
distinction are diminished by women skilfully, violently, and frequently displaying 'masculine capacities' deemed central to what it is to 'be a man'. In this, sporting capital is distributed amongst men and women, where women can be seen to be some of the best fighters in their respective clubs.

The status women can achieve in the sport may indeed lead to reinterpretations of women's bodies beyond conventional notions of femininity, and as such the order of men and women, however it is not clear that it subsequently renegotiates a gender order. The respect women karateka receive exists in relation to embodying what are interpreted as masculine capacities, yet seen and understood as performable by both men and women. As such the findings suggest that karate can challenge and qualify aspects of 'hegemonic masculinity' (Connell, 1990) rather than simply reinforce it or eradicate it. It does not mean that gender inequalities do not persist, or that existing stereotypes are not drawn upon within the practice of karate. Rather, with the underlying idea that men are more naturally suited to these celebrated 'masculine traits', notions of men's expected hierarchical position to women remains reproduced in the everyday club practice of karate, but reproduced on a blurry and shrinking structure, experienced with confusion, contradiction, and challenge.

In sharing the sweaty, technical, self-discovering, fast hitting, emotional experience of training together, women and men can build a respect and appreciation for the mutual skills of each other as existing on a spectrum of ability, with men and women interspersed along a hierarchy of skill. In this atmosphere, women and men's relations begin to be understood on grounds of similarity - of being karateka - rather than difference. Investigation into how these ideas of similarity are created between women and men in what is seen to be one of the last bastions of masculinity holds potential lessons not just for developing greater gender equality in sport, but for breaking down and tackling ideas of difference which act to subordinate women in society more broadly.

\section{References}

Adam, H. (1994) 'A welcome message and report', The Scottish Karate Federation Gazette, $1(4), 2$.

Anderson, E. (2008) 'I used to think women were weak': Orthodox masculinity, gender segregation, and sport', Sociological Forum, 23(2), 257-80.

Bourdieu, P. (2001) Masculine Domination (Cambridge:Polity Press).

Burstyn, V. (1999) The Rites of Men: Manhood, politics, and the culture of Sport (Toronto: University of Toronto Press).

Butler.J. (1998). 'Athletic Genders: Hyperbolic Instance and/or the Overcoming of Sexual Binarism', Stanford Humanities Review, 6(2), Available Online: http://www.stanford.edu/group/SHR/6-2/html/butler.html (Accessed May 25th 2014). 
Channon, A. (2013) 'Enter the discourse: exploring the discursive roots of inclusivity in mixed-sex martial arts', Sport in Society: Cultures, commerce, media, politics, 16(10),12931308.

Channon,A. \& Jennings, G. (2013) 'The rules of engagement: Negotiating painful and 'intimate' touch in mixed-sex martial arts', Sociology of Sport Journal, 30, 487-503.

Connell, R. W. (1990) 'An Iron Man: The Body and Some Contradictions of Hegemonic Masculinity', In Messner, Michael A. and Sabo, Donald F. (eds.) Sport, Men and the Gender Order: Critical Feminist Perspectives (Champaign Illinois: Human Kinetics), pp 83-96.

Connell, R.W (2009) 'The Question of Gender' In Gender, Cambridge: Polity Press

Connell, R.W. (2012) 'Supremacy and subversion- gender struggles in sport', Asia-Pacific Journal of Health, Sport and Physical Education, 3(3), 177-9.

Deutsch, F.M. (2007) 'Undoing Gender', Gender \& Society, 21(1), pp106-27.

Funakoshi, G. (1938/2003) The Twenty Guiding Principles of Karate (Tokyo: Kodansha International).

Grindstaff, L and West, E. (2006) 'Cheerleading and the gendered politics of sport', Social Problems, 53(4), 500-18.

Guérandel, C. \& Mennesson, C. (2007) 'Gender construction in judo interactions', International Review for the Sociology of Sport, 42(2), 167-86.

Hannerz, U. (2003) 'Being there...and there...and there! : Reflections on multi-sited ethnography', Ethnography, 4(2), 201-16.

Hargreaves, J. (1994) Sporting Females: Critical issues in the history and sociology of women's sports (London: Routledge).

Hirose, A. \& Pih, K.K. (2010) 'Men Who Strike and Men Who Submit: Hegemonic and Marginalised Masculinities in Mixed Martial Arts', Men and Masculinities, 13(2), 190-209.

Henry, J.M., \& Comeaux, H.P. (1999) 'Gender egalitarianism in coed sport: A case study of American soccer', International Review for the Sociology of Sport, 34(3), 277-90.

Hills, L.A., \& Croston, A. (2012) "It should be better all together': Exploring strategies for 'undoing' gender in coeducational physical education', Sport, Education and Society, 17(5), 591-605.

Love, A., \& Kelly, K. (2011) 'Equity or essentialism? US courts and the legitimation of girls' teams in high school sport', Gender \& Society, 25(2), 227-249.

McDonagh, E., \& Pappano, L. (2008) Playing with the boys: Why separate is not equal in sports (New York: Oxford University Press).

McNaughton, M.J. (2012) 'Insurrectionary Womanliness: Gender and the (Boxing) Ring', The Qualitative Report, 17. Article 33, 1-13. 
Mennesson, C. (2000) 'Hard' Women and 'Soft' Women: The Social Construction of Identities Among Female Boxers', International Review for the Sociology of Sport, 35: 2133.

Merton, R. K. (1972). Insiders and Outsiders: A Chapter in the Sociology of Knowledge. American Journal of Sociology. 78(1). pp 9-47.

Noel, H. (2009) 'Un-doing gendered power relations through martial arts?', International Journal of Social Inquiry, 2(2),17-37.

Spencer, D. (2012) 'Narratives of despair and loss: pain, injury and masculinity in the sport of mixed martial arts', Qualitative research in sport, exercise and health, 4(1), 117-37.

Summersdale Productions (2006). Heroes and Legends of British Karate. [DVD]. United Kingdom: Muze Europe Ltd.

Taylor,J. (2011) 'The intimate insider: negotiating the ethics of friendship when doing insider research', Qualitative Research, 11(3), 3-22.

Tillman-Healy, L.M (2006) 'Friendship as method', In Hesse-Biber,S and Leavy, P (eds.) Emergent Methods in Social Research (London: Sage), pp273-94.

Velija, P. Mierzwinski, M. \&Fortune, L. (2012) 'It made me feel powerful': women's gendered embodiment and physical empowerment in the martial arts', Leisure Studies, Available online at: http://dx.doi.org/10.1080/02614367.2012.696128

Wachs, F.L. (2002) 'Levelling the playing field: Negotiating gendered rules in coed softball', Journal of Sport \& Social Issues, 26(3), 300-16.

Wacquant, L. (2004) Body and Soul: Notebooks of an Apprentice Boxer (Oxford: Oxford University Press).

West \& Zimmerman (1987) ‘Doing Gender', Gender and Society, 1(2), 125-51.

Whitson, D. (1990) 'Sport in the Construction of Masculinity' In Messner et al. (eds.) Sport, Men, and the Gender Order (Leeds: Human Kenetics) pp19-30.

Woodward, K. (2006) Boxing, Masculinity, and Identity: The 'l' of the Tiger (Newyork: Routledge). 